\title{
Sucrase-Isomaltase Deficiency in Humans \\ Different Mutations Disrupt Intracellular Transport, Processing, and Function of an Intestinal Brush Border Enzyme
}

\author{
Hassan Y. Naim, ${ }^{\star}$ Jürgen Roth, ${ }^{\ddagger}$ Erwin E. Sterchi, ${ }^{*}$ Michael Lentze, ${ }^{*}$ Peter Milla, Jacques Schmitz," and Hans-Peter Hauri" \\ ${ }^{*}$ Department of Gastroenterology, Children's Hospital, University of Bern, CH-3010 Bern, Switzerland; ${ }^{\ddagger}$ Interdepartmental Electron \\ Microscopy and "Department of Pharmacology, Biocenter of the University of Basel, CH-4056 Basel, Switzerland; ${ }^{\S}$ Institute \\ of Child Health, University of London, London WC1N 1EH, United Kingdom; and "Department of Pediatrics, \\ Hopital des Enfants Malades, F-75743 Paris Cedex 15, France
}

\section{Abstract}

Eight cases of congenital sucrase-isomaltase deficiency were studied at the subcellular and protein level with monoclonal antibodies against sucrase-isomaltase. At least three phenotypes were revealed: one in which sucrase-isomaltase protein accumulated intracellularly probably in the endoplasmic reticulum, as a membrane-associated high-mannose precursor, one in which the intracellular transport of the enzyme was apparently blocked in the Golgi apparatus, and one in which catalytically altered enzyme was transported to the cell surface. All patients expressed electrophoretically normal or near normal high-mannose sucrase-isomaltase. The results suggest that different, probably small, mutations in the sucrase-isomaltase gene lead to the synthesis of transport-incompetent or functionally altered enzyme which results in congenital sucrose intolerance.

\section{Introduction}

Recent progress in understanding the mechanisms underlying the biogenesis and intracellular transport of membrane and secretory proteins has lead to the notion of compartmentalization of the eukaryotic cell into structurally and functionally distinct biosynthetic organelles $(1,2)$. Newly synthesized plasma membrane proteins migrate from the endoplasmic reticulum to the cell surface via the Golgi apparatus $(3,4)$. On their way to the cell surface most proteins undergo some type of covalent modification including glycosylation, fatty acid acylation, phosphorylation, or proteolytic cleavage (5-7). However, the molecular basis of selective protein transport from organelle to organelle is poorly understood $(8,9)$.

A promising approach for investigating membrane traffic is the analysis of naturally occurring phenotypes with impaired protein targeting $(10,11)$. Congenital sucrase-isomaltase deficiency (CSID), ${ }^{1}$ an autosomal recessive disease of the human

Part of this work has been published in abstract form (1987. J. Cell Biol. 105:59a).

Address reprint requests to Dr. Hauri, Department of Pharmacology, Biocenter of the University of Basel, Klingelbergstraße 70 , CH-4056 Basel, Switzerland.

Received for publication 4 November 1987 and in revised form 2 February 1988.

J. Clin. Invest.

(c) The American Society for Clinical Investigation, Inc.

0021-9738/88/08/0667/13 $\$ 2.00$

Volume 82, August 1988, 667-679 small intestine (12), may provide such a model (13). In the normal intestine, sucrase-isomaltase (SI) (see Semenza [14] for a recent review) is synthesized as a two-active site, single-chain polypeptide precursor (15-19), which is cotranslationally $\mathrm{N}$ glycosylated in the endoplasmic reticulum (pro-SI $\mathrm{h}_{\mathrm{h}}, M_{\mathrm{r}} 210$ $\mathrm{kD}$ in humans). On its rather slow transport to the cell surface (20-22) the N-linked glycans undergo trimming and further processing into complex-type oligosaccharides, and O-linked sugars are attached (23, Naim, manuscript submitted for publication). In vivo, the fully glycosylated enzyme (pro-SI ${ }_{c}, M_{r}$ $245 \mathrm{kD})$ is cleaved into its two subunits, sucrase $\left(M_{\mathrm{r}} 145 \mathrm{kD}\right)$ and isomaltase $\left(M_{\mathrm{r}} 151 \mathrm{kD}\right)$, by pancreatic proteases after insertion into the brush border (15). The enzyme complex is anchored in the brush border membrane by means of its isomaltase subunit only $(24,25)$. The functional absence of SI in patients with CSID results in failure of digestion of osmotically active di- and oligosaccharides. The molecular basis of CSID is unknown, but collective data (26) appear to confirm the suggestion of Dubs et al. (27) who postulated that CSID is not due to one single molecular defect. Two recent reports on single cases suggest that at least some of the patients can synthesize a pro-SI $\mathrm{h}_{\mathrm{h}}$-like protein which is unable to mature and migrate to the cell surface but is arrested and degraded intracellularly (13, 28 ). In the present investigation we have undertaken immunochemical and immunolabeling studies with biopsy specimens of eight patients with CSID. Our results suggest that different mutations in the SI gene that lead to different abnormalities in the processing, intracellular transport, or catalytic activity of the enzyme are the molecular basis of sucrose maldigestion.

\section{Methods}

Patients and processing of tissue. All the patients with CSID had a lifelong history of abdominal pain and diarrhea upon ingestion of sucrose. Sucrose malabsorption was established by sucrose tolerance tests, by the breath hydrogen test, and by measurements of enzyme activities in mucosal homogenates. Patient 1 is a 7-yr-old girl from the Bern area, who has already been described (20) and was reinvestigated. Patient 2 is a 12-yr-old girl from the Strasbourg area. Patients 3, 4, and 6 are a 22 -yr-old boy, a 16-yr-old girl, and a 9-mo-old male infant, respectively, from the Paris area. Patient 5 is a 9-mo-old female infant, and cases 7 and 8 are 11 -yr-old identical male twins from the London area. Control tissue was obtained from six patients who underwent the peroral biopsy procedure for diagnostic purposes other than CSID. All

1. Abbreviations used in this paper: CSID, congenital sucrase-isomaltase deficiency; endo $\mathrm{H}$, endoglycosidase $\mathrm{H}$; pro-SI $_{c}$, complex-glycosylated uncleaved precursor form of sucrase-isomaltase; pro-SIh, highmannose uncleaved precursor form of sucrase-isomaltase; SI, sucraseisomaltase. 
the peroral biopsy samples used in the present study were histologically normal. The biopsy specimens (5-30 mg wet weight) were taken with a pediatric-sized Watson capsule (Watson Products, Inc., Pasadena, CA) and were cut into several fragments approximately equal in size. One piece was immediately fixed for immunoelectron microscopy, two pieces were frozen at $-70^{\circ} \mathrm{C}$ for enzyme measurements and ${ }^{125} \mathrm{I}$-labeling experiments, respectively, and two to three pieces were placed in organ culture for the metabolic labeling of SI. The frozen tissue samples were analyzed within 1-3 mo.

Antibodies. All the monoclonal antibodies used have been described (20). They include HBB2/614 against the sucrase subunit and HBB3/705 against the isomaltase subunit of SI, HBB2/219 and HBB1/691 against native SI, HBB1/909 against lactase, HBB3/153 against aminopeptidase $\mathrm{N}$, and $\mathrm{HBB} 2 / 143$ against maltase-glucoamylase. As a negative control a monoclonal antibody (IgG1) against the major phenobarbital-inducible cytochrome P450 of rat liver, designated 10/205 was used (29). The antibodies were applied either in ascites form or were purified from ascites fluids by ammonium sulfate precipitation and DE 52 ion-exchange chromatography according to standard procedures.

$\left[{ }^{35} S\right]$ Methionine labeling in organ culture. Biopsy specimens were metabolically labeled with $150 \mu \mathrm{Ci} / \mathrm{ml}$ culture medium L- $\left[{ }^{35} \mathrm{~S}\right]-$ methionine according to Naim et al. (30). Labelings were performed for $30 \mathrm{~min}$ and $4 \mathrm{~h}$ and in one case also for $16 \mathrm{~h}$. At the end of the labeling period the tissue was chilled to $4^{\circ} \mathrm{C}$, washed three times with ice-cold homogenization buffer $(25 \mathrm{mM}$ Tris- $\mathrm{HCl}, \mathrm{pH} 8.1,50 \mathrm{mM}$ $\mathrm{NaCl}$ ), and homogenized in the same buffer containing $1 \mathrm{mM}$ phenylmethyl-sulfonyl fluoride, $1 \mu \mathrm{g} / \mathrm{ml}$ pepstatin, $5 \mu \mathrm{g} / \mathrm{ml}$ leupeptin, 17.4 $\mu \mathrm{g} / \mathrm{ml}$ benzamidine, and $1 \mu \mathrm{g} / \mathrm{ml}$ aprotinin. The homogenates were subjected to immunoprecipitation as described below.

${ }^{125}$ I-labeling. The lactoperoxidase-glucose-oxidase method was used for radioiodination of Triton X-100-solubilized mucosal tissue as described (20). $1 \mathrm{mCi}$ carrier-free $\mathrm{Na}^{125} \mathrm{I}$ was used for each iodination.

Immunoprecipitation and digestion with endoglycosidase $H$ and SDS-PAGE. $2 \mathrm{ml}$ of homogenate of each $\left[{ }^{35} \mathrm{~S}\right]$ methionine-labeled tissue fragment was solubilized with Nonidet $\mathrm{P}-40$ and sodium deoxycholate, $0.5 \%(\mathrm{wt} / \mathrm{vol})$ final concentration each, by stirring on ice for 30 $\min$. The solubilized material was centrifuged at $100,000 \mathrm{~g}$ for $1 \mathrm{~h}$ at $4^{\circ} \mathrm{C}$. The resulting supernatant was divided into two identical aliquots, and each aliquot was incubated for $2 \mathrm{~h}$ at $4^{\circ} \mathrm{C}$ with protein A-Sepharose beads to which the four monoclonal antibodies against SI had been adsorbed (20). Other brush border enzymes (i.e., aminopeptidase $\mathrm{N}$, dipeptidylpeptidase IV, lactase, maltase-glucoamylase, and angiotensin-converting enzyme) were immunoisolated for control purposes by subjecting the SI-depleted detergent extract to sequential immunoprecipitation with monoclonal antibodies that were covalently coupled to cyanogen bromide $(\mathrm{CNBr})$-activated Sepharose. Usually $35 \mu 1$ of packed immunobeads were incubated for $2 \mathrm{~h}$ at $4^{\circ} \mathrm{C}$ with $1 \mathrm{ml}$ of the depleted extract. The immunoprecipitates were washed according to Naim et al. (30). One of two immunoprecipitates was digested with endoglycosidase $\mathbf{H}$ (endo $\mathrm{H}$ ) according to Owen et al. (31) as described (30). For the epitope mapping with the SI antibodies $1 \mathrm{ml}$ of labeled homogenate was diluted with $3 \mathrm{ml}$ of homogenization buffer and solubilized as above. 1-ml aliquots were then subjected to immunoprecipitation with the different antibodies.

Identical aliquots of radioactivity $\left(1-3 \times 10^{7} \mathrm{cpm}\right)$ were used for the immunoprecipitation of ${ }^{125}$ I-labeled proteins from the patient and the control. The samples were preadsorbed to protein A-Sepharose overnight and directly immunoprecipitated at $\mathrm{pH} 8.0$ with the monoclonal antibodies adsorbed to protein A-Sepharose (13, 20). SDSPAGE was performed with $7.5 \%$ ( ${ }^{125}$ I-labeled samples) or with $5 \%$ acrylamide gels $\left(\left[{ }^{35} \mathrm{~S}\right]\right.$ methionine-labeled samples) according to Laemmli (32). The molecular mass standards were myosin (202 kD), $\beta$-galactosidase (116 kD), phosphorylase b $(97.4 \mathrm{kD})$, bovine serum albumine (66 kD), and ovalbumin (45 kD). For fluorography the gels were stained with Coomassie Blue, destained, and then soaked with Enlightning. The dried gels were exposed to Kodak SO-282 films (Eastman Kodak Co., Rochester, NY) at $-80^{\circ} \mathrm{C}$.
Immunoelectron microscopy. Biopsy samples were fixed by immersion in $3 \%$ paraformaldehyde and $0.1 \%$ glutaraldehyde followed by embedding in Lowicryl K4M as previously described (13). Immunolabeling of ultrathin sections for SI was done with the protein A-gold technique $(13,33)$

Enzyme and protein measurements. Disaccharidase activities were measured according to Dahlqvist (34) using sucrose, isomaltose, maltose, or lactose as substrate. Alkaline phosphatase (35) and aminopeptidase $\mathrm{N}$ were measured by standard methods. Protein was determined with the Bio-Rad protein assay kit (Bio-Rad Laboratories, Richmond, CA) using protein standard I.

\section{Results}

The CSID of the patients was initially detected by the sucrose challenge test and has been confirmed in the present study by the measurement of brush border enzyme activities in mucosal homogenates (Table I). Sucrase activities were either below the detection limit (cases 1 and 2) or at least 10-fold lower than the average values of control biopsies. Very low residual isomaltase activity was measurable in six cases whereas in the remaining two cases ( 7 and 8 ) the isomaltase activity was close to normal. The low residual isomaltase activity was not due to unrelated saccharidases since it was quantitatively immunoprecipitable with monoclonal antibodies against SI (not shown). Maltase activity was either normal (cases 4,7 , and 8 ) or was at least twofold reduced (remaining cases). This result is explainable by the known fact that SI contributes $70-90 \%$ to the overall brush border maltase activity while the remaining activity is due to a separate enzyme, maltase-glucoamylase, which most likely is not affected by CSID (see Fig. $3 A$, but see also Skovbjerg [36]). Lactase activity was normal with the exception of case 1 in which it was somewhat decreased and case 4 in which it was slightly elevated (Table I). The activities of other brush border enzymes including aminopeptidase $\mathrm{N}$ and alkaline phosphatase were in the normal range (not shown). These biochemical data demonstrate in all cases an isolated enzyme defect associated with SI. Furthermore, the findings of residual isomaltase activity in all the patients pointed to the possibility that CSID was not a consequence of a complete

Table I. Disaccharidase Activities in Mucosal Homogenates from Patients with Sucrase-Isomaltase Deficiency

\begin{tabular}{llcccc}
\hline & & \multicolumn{4}{c}{ Specific activity } \\
\cline { 3 - 6 } Case & Origin & Sucrase & Isomaltase & Maltase & Lactase \\
\hline \multicolumn{5}{c}{ IU/g protein } \\
1 & Bern & 0 & 4 & 27 & 13 \\
2 & Strasbourg & 0 & 3 & 29 & 25 \\
3 & Paris & 3 & 6 & 45 & 61 \\
4 & Paris & 4 & 9 & 117 & 88 \\
5 & London & 3 & 1.5 & 23 & 49 \\
6 & Paris & 3 & 1 & 57 & 55 \\
$7^{*}$ & London & 3 & $24^{\ddagger}$ & $62^{\ddagger}$ & 30 \\
$8^{*}$ & London & 3 & $25^{\ddagger}$ & $66^{\ddagger}$ & 40 \\
Normal values & $40-136$ & $35-123$ & $140-298$ & $25-64$ \\
\end{tabular}

* Identical twins.

₹ These activities, although lower than our normal values, are considered normal since they were in the range of a normal control specimen assayed in parallel. 


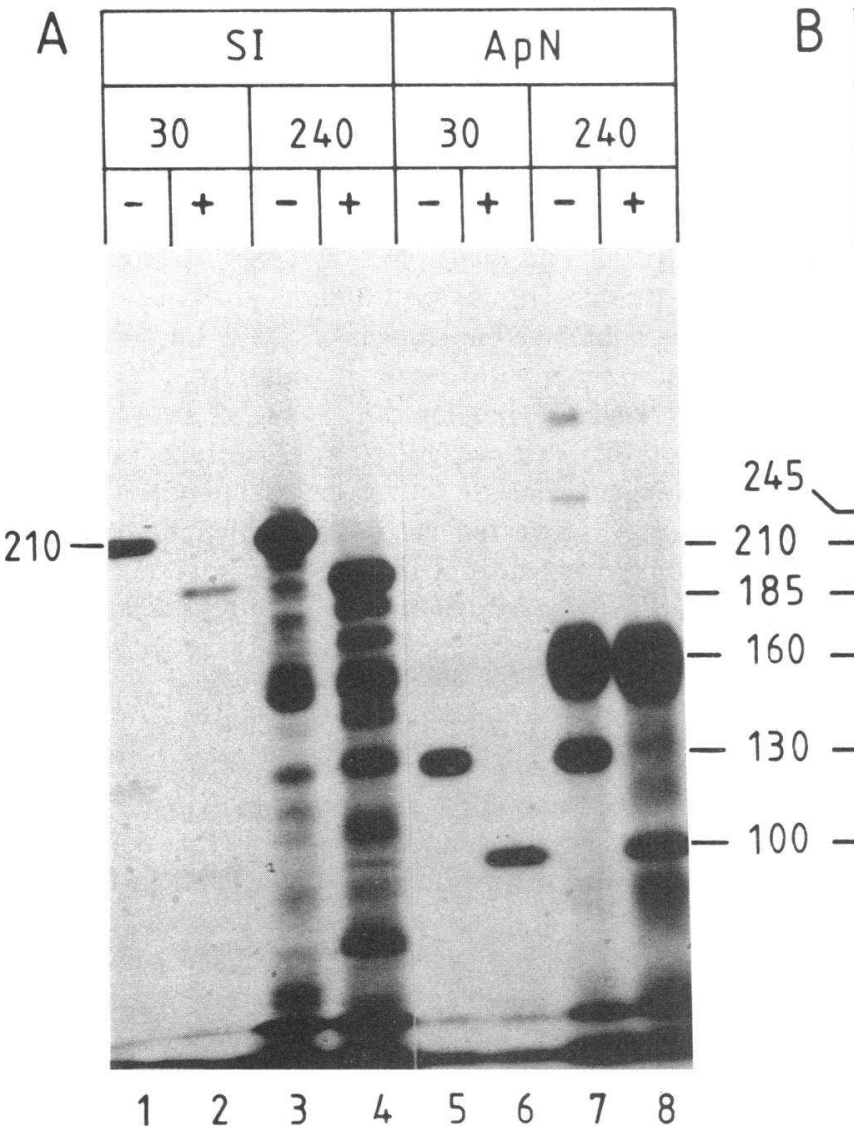

Figure 1. Metabolic labeling of sucrase-isomaltase (SI) and aminopeptidase (ApN) in organ-cultured intestinal mucosa of $(A)$ patient 1 and $(B)$ a normal subject. The tissue fragments were cultured in the presence of $150 \mu \mathrm{Ci}\left[{ }^{35} \mathrm{~S}\right]$ methionine for the indicated time periods ( $m i n$ pulse) and the immunoprecipitation was carried out with detergent-solubilized mucosal homogenates using a mixture of four

shutoff of the SI gene expression. To further analyze the defect at the subcellular and protein level, we applied immunoelectron microscopy, metabolic labeling with $\left[{ }^{35} \mathrm{~S}\right]$ methionine in organ culture, and enzymatic labeling of solubilized homogenates with $\mathrm{Na}^{125}$ I. SI was immunoprecipitated from the labeled tissue and analyzed by SDS-PAGE followed by fluorography or autoradiography. The labeling periods in organ culture (30 and $240 \mathrm{~min}$ ) were found to be optimal for the identification of pro-SI $\left(M_{\mathrm{r}} 210 \mathrm{kD}\right)$ and pro-SI $\left(M_{\mathrm{r}} 245 \mathrm{kD}\right)$ in the normal tissue on the basis of electrophoretic mobility. To further distinguish between the two forms an aliquot of the immunoprecipitate was treated with endoglycosidase $\mathrm{H}$ (endo $\mathrm{H}$ ) which cleaves high-mannose but not complex-type oligosaccharide side chains (37). The organ culture approach was expected to give information on the size, types, and epitopes of newly synthesized SI. The labeling with ${ }^{125}$ I can be expected to give information on the total amount and the molecular forms of residual SI in a steady state. Furthermore, the presence or absence of cleaved subunits $\left(M_{\mathrm{r}} 151\right.$ and $\left.145 \mathrm{kD}\right)$ will directly indicate whether or not SI is transported to the brush border. It is important to note that in some instances not all the planned experiments could be carried out due to only limited amounts of tissue being available.

Case 1. A previous investigation of a biopsy specimen of this patient revealed immunoreactive SI in the Golgi apparatus

\begin{tabular}{|c|c|c|c|c|c|c|c|c|}
\hline \multicolumn{4}{|c|}{ SI } & \multicolumn{4}{|c|}{ Ap $N$} & \\
\hline \multicolumn{2}{|c|}{30} & \multicolumn{2}{|c|}{240} & \multicolumn{2}{|c|}{30} & \multicolumn{2}{|c|}{240} & min pulse \\
\hline - & + & - & + & - & + & - & + & endo $\mathrm{H}$ \\
\hline
\end{tabular}

monoclonal antibodies against SI (lanes $1-4,9-12)$ or a single monoclonal antibody against aminopeptidase $\mathrm{N}$ (lanes 5-8, 13-16). One of two identical immunoprecipitates was treated with endoglycosidase $\mathrm{H}$ (endo $\mathrm{H}$ ) to probe for high-mannose and complex-glycosylated forms prior to SDS-PAGE while the other one was not treated. Shown are fluorograms of 5\% acrylamide gels.

(20). After ${ }^{125}$ I labeling, a protein was immunoprecipitable with an electrophoretic mobility that was indistinguishable from normal pro-SI . Neither pro-SI $_{c}$ nor cleaved subunits were detectable. This patient has now been rebiopsied for metabolic labeling studies using $\left[{ }^{35} \mathrm{~S}\right]$ methionine. After a $30-\mathrm{min}$ pulse a $210-\mathrm{kD}$ protein was immunoprecipitable from the patient's mucosa (Fig. $1 A$, lane 1 ) which on SDS-gels comigrated with pro-SI $\mathrm{h}_{\mathrm{h}}$ of the control (lane 9). Treatment with endo $\mathrm{H}$ converted the precursors to $M_{\mathrm{r}} 185-\mathrm{kD}$ proteins (lanes 2 and 10 ). The $210-\mathrm{kD}$ protein remained the major band in the sample of the patient even after 4-h labeling (lane 3) and its endo $\mathrm{H}$ sensitivity was maintained (lane 4). In contrast, with the control tissue an additional band of $245 \mathrm{kD}$ was visible at that time, which was endo $\mathrm{H}$ resistant and hence represents pro-SI (Fig. $1 B$, lanes 11 and 12 ). The findings in this patient demonstrate synthesis of pro-SI $\mathrm{S}_{\mathrm{h}}$-like molecules but absence of conversion to pro-SI $I_{c}$. Additional bands in the $150-200-\mathrm{kD}$ range observed after $4 \mathrm{~h}$ (lane 3) are assumed to indicate intracellular degradation of the pro-SI $\mathrm{h}_{\mathrm{h}}$-like protein and not a general proteolytic artifact since they were not present after 30 min nor were such bands observed with the control sample. Moreover, immunoprecipitation with antibodies against aminopeptidase $\mathrm{N}$ did not result in the presence of degradation products (lanes 7 and 15$)$.

To examine whether the absence of pro-SI ${ }_{c}$ was indeed due 
to isolated CSID or due to a more general defect in glycosylation or a disturbance of protein transport the biogenesis of aminopeptidase $\mathbf{N}$ was studied. In both the patient and the control aminopeptidase $\mathrm{N}$ was synthesized as an endo $\mathrm{H}$-sensitive, $130-\mathrm{kD}$, high-mannose precursor which was efficiently converted to the endo H-resistant, $160-\mathrm{kD}$, fully glycosylated form within $4 \mathrm{~h}$ (Fig. 1). We conclude therefore that the disturbance of glycoprotein maturation in the patient is restricted to SI and does not reflect a general defect in glycosylation.

To obtain information on a possible gross structural alteration of the residual SI, immunoprecipitation experiments with monoclonal antibodies HBB 2/614, HBB 2/219, HBB $1 / 691$, and HBB 3/705 against four different epitopes of SI were carried out (20). After ${ }^{125} \mathrm{I}$ labeling, the $210-\mathrm{kD}$ protein was immunoprecipitable with each of the antibodies, suggesting that the four epitopes were not changed (not shown). Reactivity with antibody $\mathrm{HBB} 3 / 705$, which recognizes an early form of pro-SI $\mathrm{h}_{\mathrm{h}}(20)$ was weak in comparison to the other antibodies but was comparable to normal controls.

Overall, the data confirm and extend the conclusions drawn in our previous study (13) that CSID in this patient is due to the synthesis of electrophoretically normal pro-SI which, however, fails to undergo complex-type glycosylation as an intact molecule. The finding that pro- $\mathrm{SI}_{h}$ of the patient is electrophoretically indistinguishable from normal pro-SI $\mathrm{S}_{h}$ suggests normal trimming of its high-mannose glycans. We believe therefore that the abnormal pro-SI $\mathrm{S}_{\mathrm{h}}$ is degraded either in the endoplasmic reticulum before exit to the Golgi or in the cis-Golgi apparatus.

Cáse 2. This case is enzymatically (Table I) and immunocytochemically similar to case 1 . It is characterized by the lack of immunoreactive SI in the brush border and a significant immunolabel in the medial- and trans-Golgi cisternae including the trans-Golgi network and smooth vesicular profiles (Fig. $2, a-c)$. Immunolabel was absent over the endoplasmic reticulum and lysosomes. Electrophoretically normal pro-SI $\mathrm{S}_{h}$ was immunoprecipitable from ${ }^{125} \mathrm{I}$-labeled mucosal protein with a mixture of the four monoclonal antibodies while no pro-SI nor SI subunits were detectable (Fig. $3 A$ ). When used individually, antibodies HBB 1/691 and HBB 2/219 failed to immunoprecipitate the pro- $\mathrm{SI}_{h}$ of the patient suggesting that the corresponding two epitopes were altered (Fig. $3 \mathrm{~B}$, lanes 8 and 10). The reactivity of pro-SI $\mathrm{SI}_{h}$ with antibodies $\mathrm{HBB} 2 / 614$ and $\mathrm{HBB}$ $3 / 705$ was identical to the control. On the basis of this epitope mapping we conclude that the mutation of case 2 is most likely different from that of case 1 . It was not possible to do organ culture experiments with the mucosa of this patient.

Cases 3 and 4. These cases are dëscribed togethẹ since, although from two unrelated families, they express a rather similar phenotype which, however, is strikingly different from the two previous cases. Organ culture experiments showed that in both biopsy specimens a pro-SI $\mathrm{S}_{\mathrm{h}}$-like protein with slightly elevated $M_{\mathrm{r}}(212$ instead of $210 \mathrm{kD}$; Fig. 4, lanes 1, 9, 17, and 18) was synthesized. However, after endo $H$ treatment the size of pro-SI $\mathrm{h}$ was identical to the control. The $M_{\mathrm{r}}$ difference of $\sim 2 \mathrm{kD}$ can therefore be ascribed to differences in the carbohydrate moiety. After a 4 -h pulse with $\left[{ }^{35} \mathrm{~S}\right]$ methionine, all immunoprecipitable SI of patient 3 had an unchanged $M_{\mathrm{r}}$, while in patient 4 a small amount of pro-SI $_{h}(10 \%$ as determined by densitometry) was converted to an endo-H-resistant 245-kD form (Fig. 4, lanes 11 and 12). Interestingly, part of the $212-\mathrm{kD}$ protein of patient 3 was also endo $\mathrm{H}$ resistant after $4 \mathrm{~h}$.
This latter finding is unlikely to be due to incomplete action of endo $\mathrm{H}$ since other SI immunoprecipitates as well as immunoprecipitates obtained with aminopeptidase $\mathbf{N}$ run in parallel showed complete digestion (Fig. 4). Complex-glycosylated aminopeptidase $\mathrm{N}$ also showed a higher mean electrophoretic $M_{\mathrm{r}}$ in case 4 than in case 3 suggesting differences in the complex-type glycans. This may reflect differences in blood groups of the two patients. Human brush border enzymes are indeed known to carry blood group antigens $(38,39)$. Immunoprecipitation experiments with detergent-solubilized ${ }^{125}$ I-labeled proteins were carried out for case 3. Fig. 5 shows that the pro-SI $\mathrm{h}_{\mathrm{h}}$-like protein was recognized by each of the four monoclonal antibodies against SI. Interestingly, antibody HBB3/705 very efficiently recognized the mutated SI (lane 6). Under nondenaturing conditions of immunoprecipitation this antibody is specific for a very early form of pro-SI $\mathrm{Sh}_{h}$ whereas later forms of pro-SI $\mathrm{h}_{\mathrm{h}}$ as well as pro-SI $\mathrm{S}_{\mathrm{c}}$ are only recognized when denatured (20). This indicates that in the patient pro-SI $\mathrm{SI}_{\mathrm{h}}$ fails to undergo an early maturation event. There was a striking apparent overexpression of pro-SI $\mathrm{S}_{h}$ in the patient when compared to the normal control (Fig. 5, lanes 1 and 2) but no cleaved subunits were detectable, suggesting that the enzyme was not transported to the brush border. To evaluate if pro-SI of the patient was still membrane associated, an aliquot of the homogenate was freeze-thawed, sonicated, and subjected to ultracentrifugation $(100,000 \mathrm{~g}$ for $1 \mathrm{~h})$. The resulting particular and soluble fractions were separately radioiodinated and immunoprecipitated. Fig. $5 B$ shows that pro-SI $\mathrm{h}_{\mathrm{h}}$ was quantitatively precipitated from the particulate fraction and hence was probably still membrane bound. Immunoelectron microscopy was not performed with these two cases.

Case 5. This patient combines features of cases 1 and 4 . Similarly to case 1 , its SI was synthesized as an electrophoretically normal, endo-H-sensitive, $210-\mathrm{kD}$ protein (Fig. 6, lanes 1 and 2) at close to normal levels. There was a weak immunolabeling of the Golgi àpparatus but complete absence of immunoreactive SI from the brush border as revealed by immunoelectron microscopy (not shown). Unlike case 1 but similarly to case 4, a small fraction of the pro-SI ${ }_{h}$ underwent complex glycosylation (Fig. 6, lanes 3 and 4). No cleaved subunits were immunoprecipitable from the ${ }^{125}$ I-labeled homogenate (not shown). Biosynthesis and processing of aminopeptidase $\mathrm{N}$ proceeded normally. Newly synthesized pro-SI $\mathrm{S}_{h}$ was immunoprecipitable with all four anti-SI antibodies whereas pro-SI $\mathrm{S}_{c}$, as expected, was not recognized by $\mathrm{HBB} 3 / 705$ (Fig. $6 \mathrm{~B}$ ). The strong reactivity of pro-SI $\mathrm{S}_{h}$ with antibody $3 / 705$ suggests that maturation of the proform is not taking place or is slowed down. Overall, these results suggest synthesis but inefficient maturation of pro-SI $\mathrm{S}_{\mathrm{h}}$ along the endoplasmic reticulum to the trans-Golgi pathway. The enzyme is probably degraded intracellularly as indicated by the presence of several immunoreactive proteins of lower $M_{\mathrm{r}}$ (Fig. 6, lane 3).

Case 6. This patient is similar but not identical to case 1 . Its mucosa was able to synthesize pro-SI $\mathrm{I}_{\mathrm{h}}$ which failed to undergo complex glycosylation even after $16 \mathrm{~h}$ (Fig. $7 \mathrm{~A}$ ). The total amount of ${ }^{125} \mathrm{I}$-labeled pro-SI $\mathrm{h}_{\mathrm{h}}$ was significantly lower than that of the control specimen (Fig. $7 B$, lanes 2 and 3) while the amount of immunoprecipitable lactase was comparable (lanes 5 and 6). Newly synthesized pro-SI $\mathrm{h}_{\mathrm{h}}$ was immunoprecipitable with all four antibodies to SI (Fig. 7 C). Most notably strong reactivity was observed with antibody HBB 3/705 (lane 2). As in the previous cases the biosynthesis of aminopeptidase $\mathrm{N}$ was 

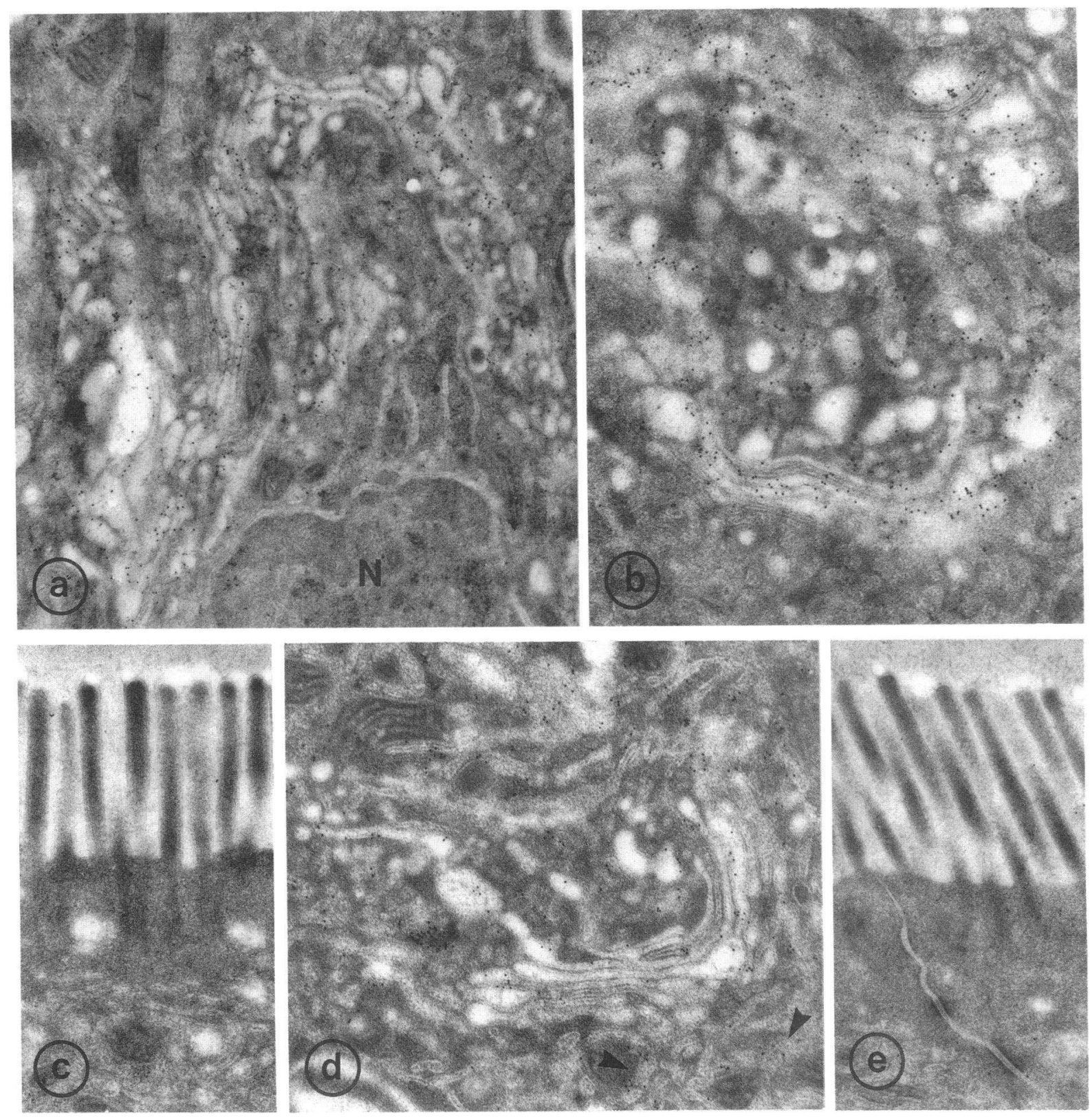

Figure 2. Immunolocalization of SI in intestinal absorptive cells of two patients with CSID. In case 2 intense immunolabel is present in the cisternal stack and the trans-Golgi network $(a, b)$ but undetectable in the brush border $(c)$. In case 6 the pattern of immunolabel in the Golgi apparatus $(d)$ is similar as in case 2 but less intense and addi-

normal (Fig. $7 A$ ). At $16 \mathrm{~h}$ the radioactivity in pro-SI $\mathrm{h}_{\mathrm{h}}$ was significantly lower than at $4 \mathrm{~h}$. Aminopeptidase $\mathrm{N}$ showed the opposite trend. Since in normal biopsies the incorporation of $\left[{ }^{35} \mathrm{~S}\right]$ methionine into both $\mathrm{SI}$ and aminopeptidase $\mathrm{N}$ regularly increased between 4 and $16 \mathrm{~h}$ (not shown), the results of the patient most likely reflect an increased intracellular turnover of the residual SI. Weak immunolabeling was detectable by immunoelectron microscopy over the Golgi apparatus and surrounding smooth vesicular and tubular profiles while the brush border showed no labeling (Fig. 2, $d$ and $e$ ). The data suggest that in this patient somewhat lower than normal levels of pro-SI $\mathrm{I}_{\mathrm{h}}$ were synthesized or persisted and that SI failed to undergo maturation and transport to the cell surface. tional immunolabel is found in the smooth endoplasmic reticulum (arrowheads in $d$ ). The brush border is not labeled $(e) . N$, part of the nucleus. Magnifications: (a) 29,000; (b) 37,000; (c) 27,500; (d) 34,$000 ;(e) 27,500$.

Cases 7 and 8. These patients are identical male twins. Already their high residual isomaltase activity in mucosal homogenates (Table I) indicated a phenotype different from the previous cases. In fact, the organ culture experiment showed normal biosynthesis and processing of SI (Fig. $8 \mathrm{~A}$ ). By electron microscopy the brush border exhibited immunolabel of variable intensity (Fig. 9). In addition, weak immunolabel occurred along the basolateral plasma membrane, over the Golgi apparatus and the smooth endoplasmic reticulum in apical cell regions. In accord with the brush border labeling is the presence of cleaved enzyme subunits on gels run with immunoprecipitates of ${ }^{125} \mathrm{I}$-labeled SI of the patient (Fig. $8 \mathrm{C}$ ). As with cases 3,4 , and 6 , we believe that the $M_{\mathrm{r}}$ differences between the 


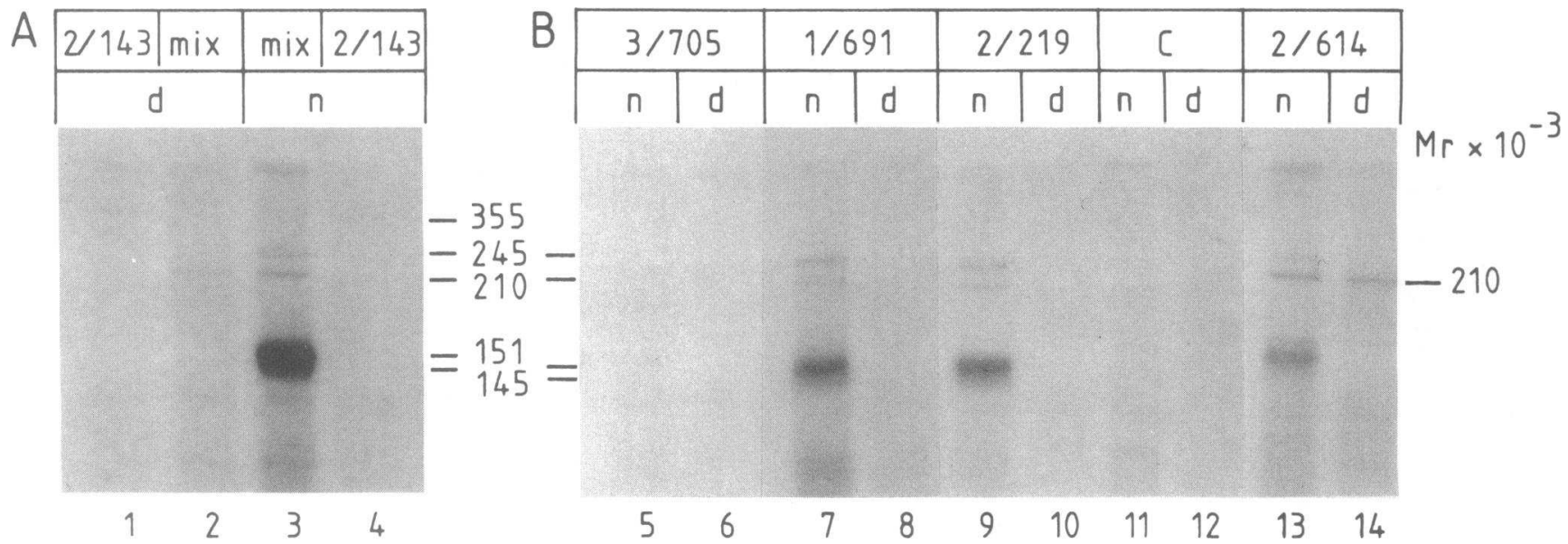

Figure $3 .{ }^{125}$ I-labeled SI of patient $2(d)$ and of a normal control $(n)$. Triton X-100-solubilized mucosal homogenate was enzymatically labeled with $\mathrm{Na}^{125} \mathrm{I}$ and SI was immunoprecipitated with either a mixture ( $m i x)$ of four monoclonal antibodies $(A)$ or with single monoclonal antibodies to sucrase-isomaltase $(B)$. Lanes 2 and 3 , anti-SI antibodies; lanes 1 and 4, monoclonal antibody HBB 2/143 against maltase-glucoamylase $\left(M_{\mathrm{r}} 355 \mathrm{kD}\right)$ used as a control; lanes 11 and 12) monoclonal antibody $10 / 205$ against the major phenobarbital inducible cytochrome $\mathbf{P 4 5 0}$ of rat liver used as a negative control (Bonkovsky et al. [29]). Shown are autoradiograms of $7.5 \%$ acrylamide gels. complex-glycosylated forms of the patients and the control are due to blood group-related carbohydrate antigens. This interpretation is corroborated by the organ culture experiments which showed identical $M_{\mathrm{r}}$ of newly synthesized pro-SI $\mathrm{S}_{\mathrm{h}}$ (with or without endo $\mathrm{H}$ treatment) for the patients and a different control (not shown). However, the $M_{\mathrm{r}}$ differences in Fig. $8 C$ is not due to the $\mathrm{ABO}$ blood-typing system since both the pa- tients and the control had blood group 0 . The epitope mapping gave results that were indistinguishable from the normal control (Fig. 8 B). Antibody HBB 3/705 (lane 9) showed a weak reaction with pro-SI $\mathrm{S}_{\mathrm{h}}$ while the other three antibodies reacted strongly with both pro-SI ${ }_{h}$ and pro-SI $I_{c}$. Taken together the results suggest that in these twins catalytically altered SI was synthesized at normal levels and that the mutation had

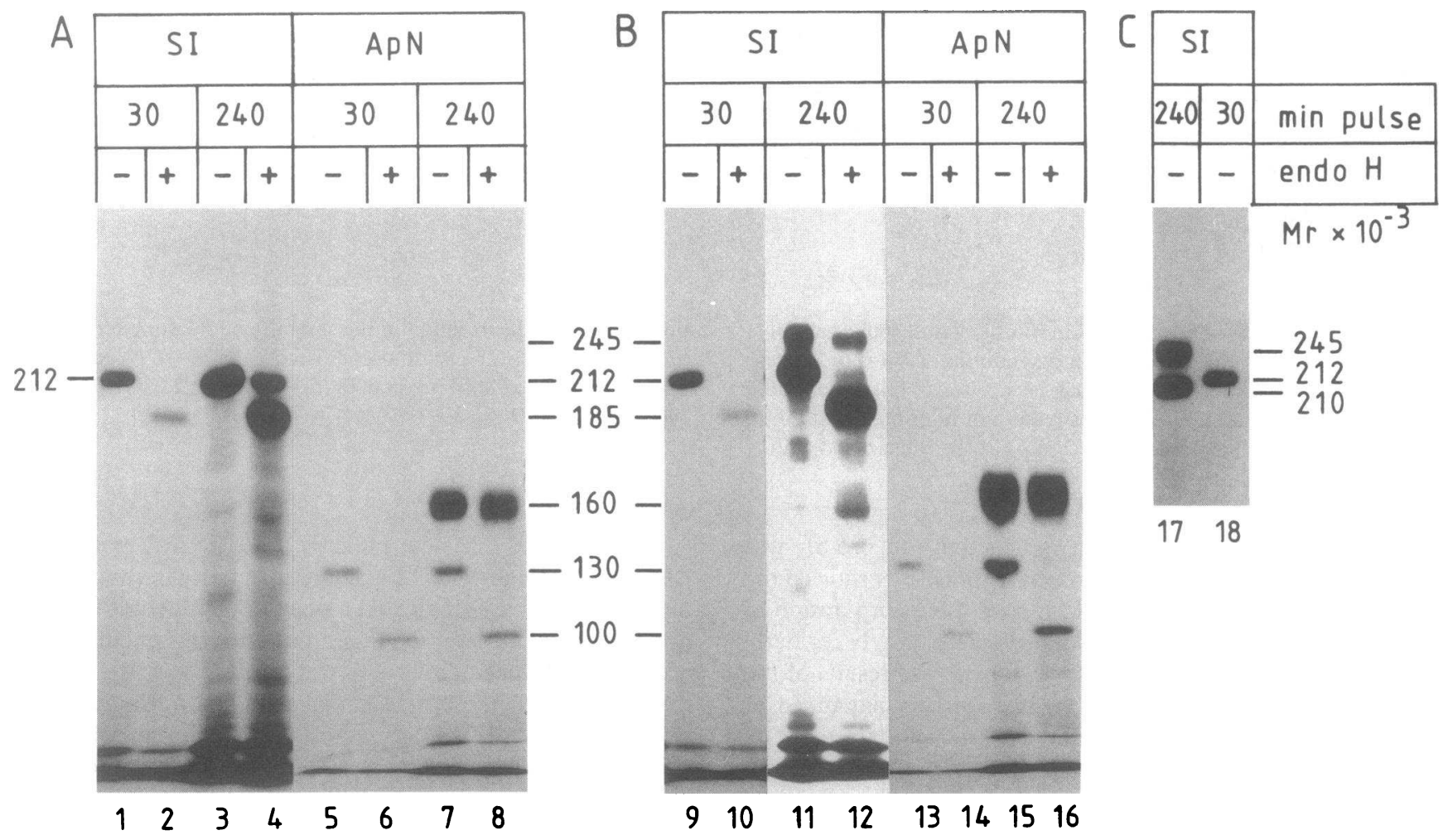

Figure 4. Electrophoresis of ${ }^{35} \mathrm{~S}$-labeled SI and aminopeptidase $\mathrm{N}$ of $(A, C)$ patient 3 and $(B)$ patient 4 . Intestinal tissue fragments were metabolically labeled and immunoprecipitated as described in the legend to Fig. 1. (C) Direct comparison of SI immunoisolated from a control (lane 17) and from patient 3 (lane 18). 


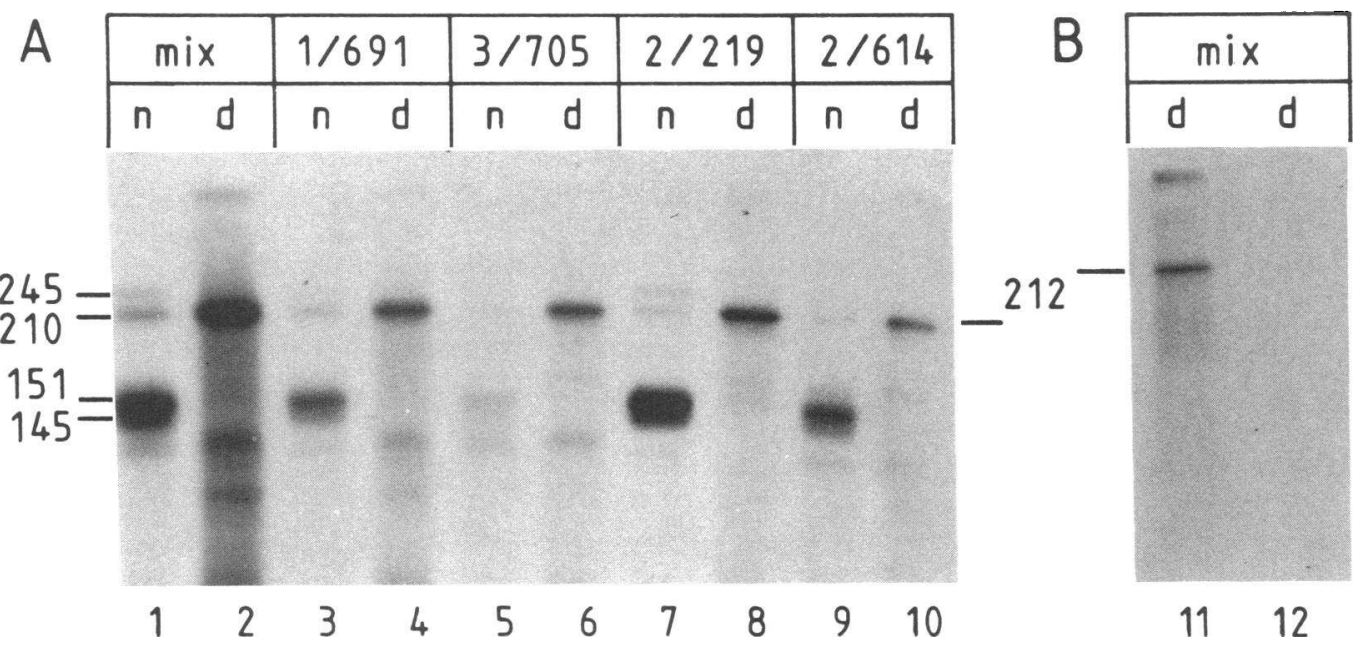

Figure 5. Electrophoresis of ${ }^{125} \mathrm{I}$-labeled SI from patient $3(d)$ and from a normal control $(n)$. $(A)$ Mucosal homogenates were solubilized, labeled, and immunoprecipitated as described in the legend to Fig. 3. (B) An aliquot of the mucosal homogenate of the patient was

freeze-thawed, sonicated, and subjected to centrifugation $(100,000 \mathrm{~g}$ for $1 \mathrm{~h}$ ). The resulting pellet (lane 11) and supernatant (lane 12) fractions were separately radioiodinated, immunoprecipitated with a mixture of the four antibodies to SI, and separated by SDS-PAGE.

affected the active site of the sucrase subunit with little effect on the isomaltase subunit. This alteration did not abolish SI transport to the cell surface.

\section{Discussion}

This study has revealed different phenotypes of CSID in humans. Combining the results obtained with the different

approaches, it appears that every CSID case (except those of the identical twins) may have arisen from different allelic mutations of the SI gene (Table II). The validity of this interpretation ultimately requires analysis of the mutations at the gene level. However, we can already be certain of the presence of at least three phenotypes.

Phenotype I, as exemplified by cases 3 and 4 , is characterized by a substantial overexpression of a slightly larger than
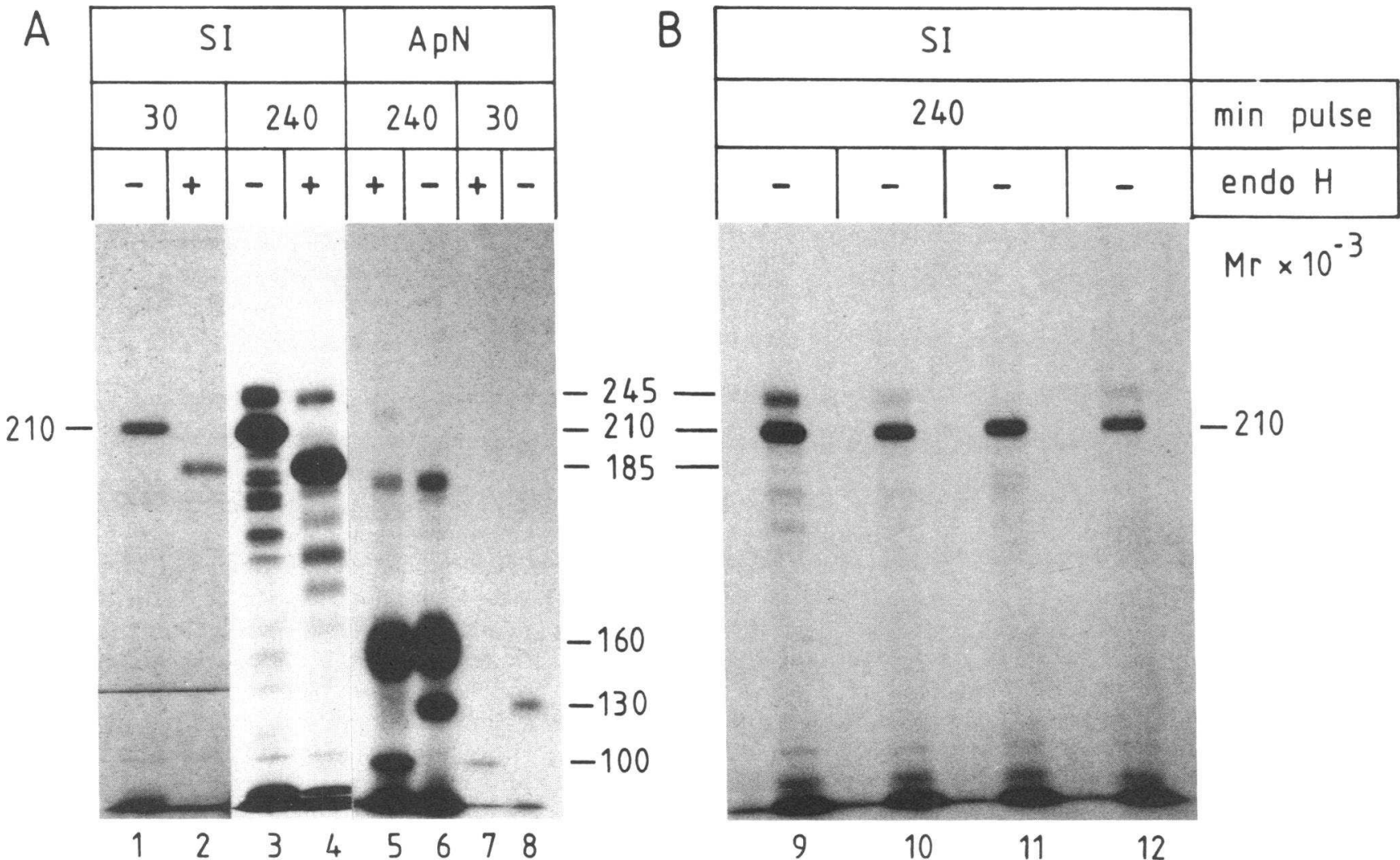

Figure 6. (A) Electrophoresis of ${ }^{35} \mathrm{~S}$-labeled SI and aminopeptidase $\mathrm{N}$ of patient 5. (B) Immunoisolation of ${ }^{35} \mathrm{~S}$-labeled SI from the patient with antibodies HBB 2/219 (lane 9), HBB 2/614 (lane 10), HBB 3/705 (lane 11), and HBB 1/691 (lane 12). Intestinal tissue fragments were metabolically labeled and immunoprecipitated as described in the legend to Fig. 1 and in Methods. 

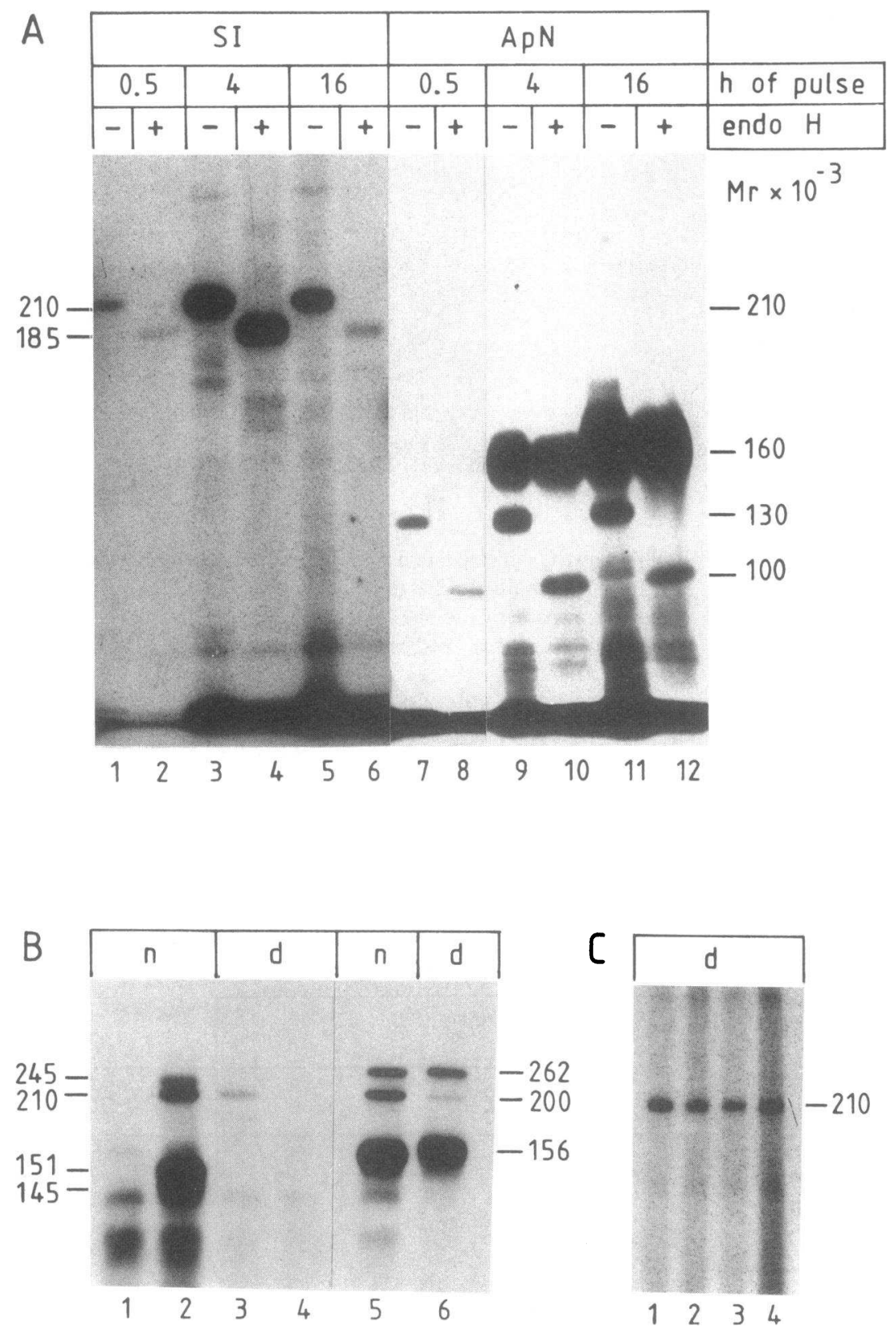

Figure 7. Electrophoresis of $(A, C){ }^{35} \mathrm{~S}$-labeled and $(B){ }^{125} \mathrm{I}$-labeled brush border enzymes of patient 6 . Intestinal tissue fragments were labeled and immunoprecipitated as described in the legends to Figs. 1 and 3. (B) SI (lanes 2 and 3) or lactase (lanes 5 and 6 ) were immunoisolated from the patient $(d)$ or from a normal control (n). Control immunoprecipitates performed with an antibody against the major phenobarbital-inducible cytochrome $\mathbf{P 4 5 0}$ of rat liver are shown in lanes 1 and 4 . The apparent $M_{\mathrm{r}}$ differences of the fully glycosylated lactase molecules $\left(M_{\mathrm{r}} 262\right.$ and 156) in lanes 5 vs. 6 are assumed to be due to blood group differences. $(C)$ Epitope mapping of the patient's SI (4-h pulse) with monoclonal antibodies HBB 1/691, HBB 3/705, HBB 2/614, and HBB 2/219 (lanes 1-4). The 262-kD lactase band represents an endo H-resistant form which most likely has arisen by the amalgamation of two complex glycosylated lactase subunits (Hauri, H. P., unpublished observation) and is not the uncleaved pro-lactase (ref. 30). normal pro-SI $\mathrm{h}_{\mathrm{h}}$, which is inefficiently converted to pro-SI $\mathrm{SI}_{\mathrm{c}}$ and does not reach the brush border. The endo $\mathrm{H}$ experiments clearly indicated that the increased apparent $M_{\mathrm{r}}$ of $2 \mathrm{kD}$ can be ascribed to excess carbohydrate which may either be due to inefficient trimming, to the generation of a novel glycosylation site, or to the exposure of an existing but normally hidden glycosylation site. The latter two possibilities are rather unlikely, since an additional oligosaccharide side chain can be expected to also increase the apparent $M_{\mathrm{r}}$ of pro-SI $\mathrm{S}_{\mathrm{c}}$. However, this was not observed. The most likely interpretation for the defect leading to phenotype I is a transport block of SI in the endoplasmic reticulum resulting in incomplete carbohydrate trimming. The initial steps of trimming of high-mannose glycans, i.e., the removal of glucose and some mannose residues, are known to take place in the endoplasmic reticulum while the final trimming of mannose residues occurs in the Golgi apparatus and is catalyzed by the Golgi enzymes mannosidase
I and II $(5,40)$. Inhibition of glucose removal by deoxynojirimycin or methyl-deoxynojirimycin in organ or Caco-2 cell culture results in a pro-SI $\mathrm{h}_{\mathrm{h}}$ with an apparent $M_{\mathrm{r}}$ increase of 2-3 $\mathrm{kD}$ whereas inhibition of mannosidase I by deoxymannojirimycin results in electrophoretically normal pro-SI which can still migrate to the Golgi apparatus (Matter, K., H. Naim, and H. P. Hauri, unpublished results). These inhibitor studies suggest that the transport of pro-SI $\mathrm{S}_{h}$ in phenotype $\mathrm{I}$ is blocked proximal to the cis-Golgi and that the proposed incomplete trimming is a consequence rather than the underlying cause for the failure in transport. This phenotype of CSID is reminiscent of the $Z$ variant of human $\alpha_{1}$-antitrypsin deficiency (41). In this disease $85 \%$ of newly synthesized $\alpha_{1}$-antitrypsin, which is normally secreted, accumulates in the endoplasmic reticulum of hepatocytes due to a point mutation at amino acid position 342 (42). The $\mathrm{Z}$ polypeptide is normally produced but its intracellular transport is blocked at a high-mannose stage of 
Table II. Immunochemical Analysis of Sucrase-Isomaltase in Congenital Sucrase-Isomaltase Deficiency: Summary of Data

\begin{tabular}{|c|c|c|c|c|c|c|c|c|}
\hline \multirow[b]{2}{*}{ Molecular form and/or method } & & \multicolumn{7}{|c|}{ Patient } \\
\hline & & 1 & 2 & 3 & 4 & 5 & 6 & $7 / 8$ \\
\hline \multirow[t]{2}{*}{ Pro-SI ${ }_{h}$} & {$\left[{ }^{35}\right.$ S]Met } & + & NA & $+^{*}$ & $t^{*}$ & + & + & + \\
\hline & ${ }^{125} \mathrm{I}$ & $+^{*}$ & + & ++ & NA & + & $(+)$ & + \\
\hline \multirow[t]{2}{*}{ Pro-SI $_{c}$} & {$\left[{ }^{35}\right.$ S]Met } & - & NA & $-\S$ & $(+)$ & $(+)$ & - & + \\
\hline & ${ }^{125} I$ & - & - & - & NA & $(+)$ & - & + \\
\hline \multirow[t]{2}{*}{ SI subunits } & {$\left[{ }^{35}\right.$ S $]$ Met } & - & NA & - & - & - & - & - \\
\hline & ${ }^{125} \mathrm{I}$ & - & - & - & NA & - & - & + \\
\hline \multirow[t]{2}{*}{ Epitopes } & {$\left[{ }^{35}\right.$ S]Met } & NA & NA & - & NA & $4 / 4$ & $4 / 4$ & $4 / 4$ \\
\hline & ${ }^{125} \mathrm{I}$ & $4 / 4$ & $2 / 4$ & $4 / 4$ & NA & NA & NA & $4 / 4$ \\
\hline \multirow{2}{*}{$\begin{array}{l}\text { Reactivity with antibody } \\
\text { HBB3/705 }\end{array}$} & {$\left[{ }^{35}\right.$ S $] M e t " 11$} & NA & NA & NA & NA & ++ & ++ & + \\
\hline & ${ }^{125} \mathrm{I}$ & + & + & ++ & NA & NA & NA & NA \\
\hline \multirow[t]{2}{*}{ Degradation products } & {$\left[{ }^{35}\right.$ S]Met } & + & NA & + & - & + & + & - \\
\hline & ${ }^{125} \mathbf{I}$ & $t^{\ddagger}$ & - & + & NA & + & + & - \\
\hline Immunolabeling & & Golgi $^{\ddagger}$ & Golgi & NA & NA & Golgi & Golgi & Brush border \\
\hline
\end{tabular}

Arbitrary units are based on densitometric scanning of fluorograms and autoradiograms which were obtained from gels run with equal aliquots of radioactivity (patient vs. control): ++ , overexpressed relative to control; + , present at equal amounts compared to control; $(+)$, present at lower amounts compared to control; -, not detectable; NA, not analyzed. ${ }^{*}$ Elevated $M_{\mathrm{r}}(212$ instead of $210 \mathrm{kD})$. ${ }^{\ddagger} \mathrm{Hauri}$ et al. (13). ${ }^{\S}$ No authentic pro-SI $I_{c}$ detectable but presence of endo H-resistant, 212-kD protein. " 240 -min pulse.

processing (43). Most of the blocked $\mathrm{Z}$ polypeptide appears to be removed by intracellular degradation. However, it is important to note that pro-SI $\mathrm{S}_{h}$ of phenotype I accumulates in a membrane-associated form.

Phenotype II, represented by cases 1 and 2, shows synthesis of electrophoretically indistinguishable pro-SI $\mathrm{S}_{\mathrm{h}}$ at virtually normal levels, no conversion to pro-SI $\mathrm{c}_{c}$, no SI at the cell surface but increased intensity of label in the medial and trans cisternae of the Golgi apparatus. The weak reaction of ${ }^{125} \mathrm{I}$-labeled pro-SI $_{h}$ with the conformation-specific antibody $\mathrm{HBB} 3 / 705$, which was indistinguishable from that of the normal control, indicates that the residual enzyme in phenotype II has undergone a more complete maturation than in phenotype I. We believe that in these cases SI is normally transported to the Golgi apparatus but is degraded prior to complex glycosylation possibly in the cis-Golgi apparatus. A recently described case of CSID by Lloyd and Olsen (28) showed some similar features and may therefore belong to the same phenotype. Our cases 5 and 6 exhibit a similar phenotype. However, the presence of some complex-type pro-SI in case 5 and the strong reactivity of antibody HBB3/705 with the residual SI in case 6 argue in favour of different mutations.

In phenotype III, represented by the identical twins (cases 7 and 8), SI is transported to the brush border and cleaved into subunits. In these patients the mutation affects the catalytic activity of the sucrase subunit only, with little consequences for intracellular transport. However, the highly variable immunolabeling of the brush border and the presence of immunolabel over the basolateral membrane which was never observed with control specimens suggests a partial missorting of SI.

The present data lend conclusive support to the hypothesis of Dubs et al. (27), who proposed that different mutations may lead to CSID. These authors reported presence of cross-reacting material in enzyme-deficient intestine by use of indirect immunofluorescence. These data apparently conflicted with those of Gray et al. (44), who demonstrated absence of enzyme variant in 7 patients with CSID by radioimmunoassay. Surprisingly, Gray et al. (44) found a higher than normal fraction of enzymatically inactive SI with heterozygote carriers. This finding was suggested to reflect a conversion of active to inactive enzyme in the heterozygotes owing to substrate deprivation. Our results offer another explanation of the data of these authors. It seems likely that the CSID patients described in that study had in fact phenotype II, i.e., presence of pro-SI $\mathrm{h}_{\mathrm{h}}$. This intracellular form may have escaped detection by radioimmunoassay due to the small amount present or was degraded during the incubation of the homogenate with papain. In heterozygote carriers on the other hand, the enzyme variant may have been stabilized and even transported to the cell surface by participating in the formation of dimers (45) with the wildtype enzyme from the normal allele as has been found in other autosomal recessive diseases (46). How can other reported cases of CSID be accomodated within the three phenotypes? Preiser et al. (47) and Schmitz et al. (48) using acrylamide gel electrophoresis of detergent-solubilized brush border membranes from CSID patients found an absence of the protein band which is associated with SI. These patients may have either been phenotype I or phenotype II. Some of the phenotypes described by Schmitz et al. (49) and Triadou et al. (50) in which a substantial amount of residual SI protein was found may belong to phenotype I, the more so since they also originate from the Paris area. Some other cases in which electrophoretically abnormal isomaltase (51) or apparently free isomaltase (52) were found may be different from the phenotypes described here.

What lessons can be learned from CSID with regard to our understanding of the mechanisms for intracellular protein transport? It is evident that small, electrophoretically invisible changes of the primary structure can arrest intracellular trans- 


\begin{tabular}{|c|c|c|c|c|c|c|}
\hline \multicolumn{3}{|c|}{ SI } & \multicolumn{4}{|c|}{ ApN } \\
\hline 30 & & & 31 & & & \\
\hline$-1+$ & - & + & - & + & - & + \\
\hline
\end{tabular}

\begin{tabular}{|c|c|c|c|}
\hline \multicolumn{3}{|c|}{ SI } & \\
\hline \multicolumn{3}{|c|}{240} & min pulse \\
\hline- & - & - & endo $H$ \\
\hline
\end{tabular}
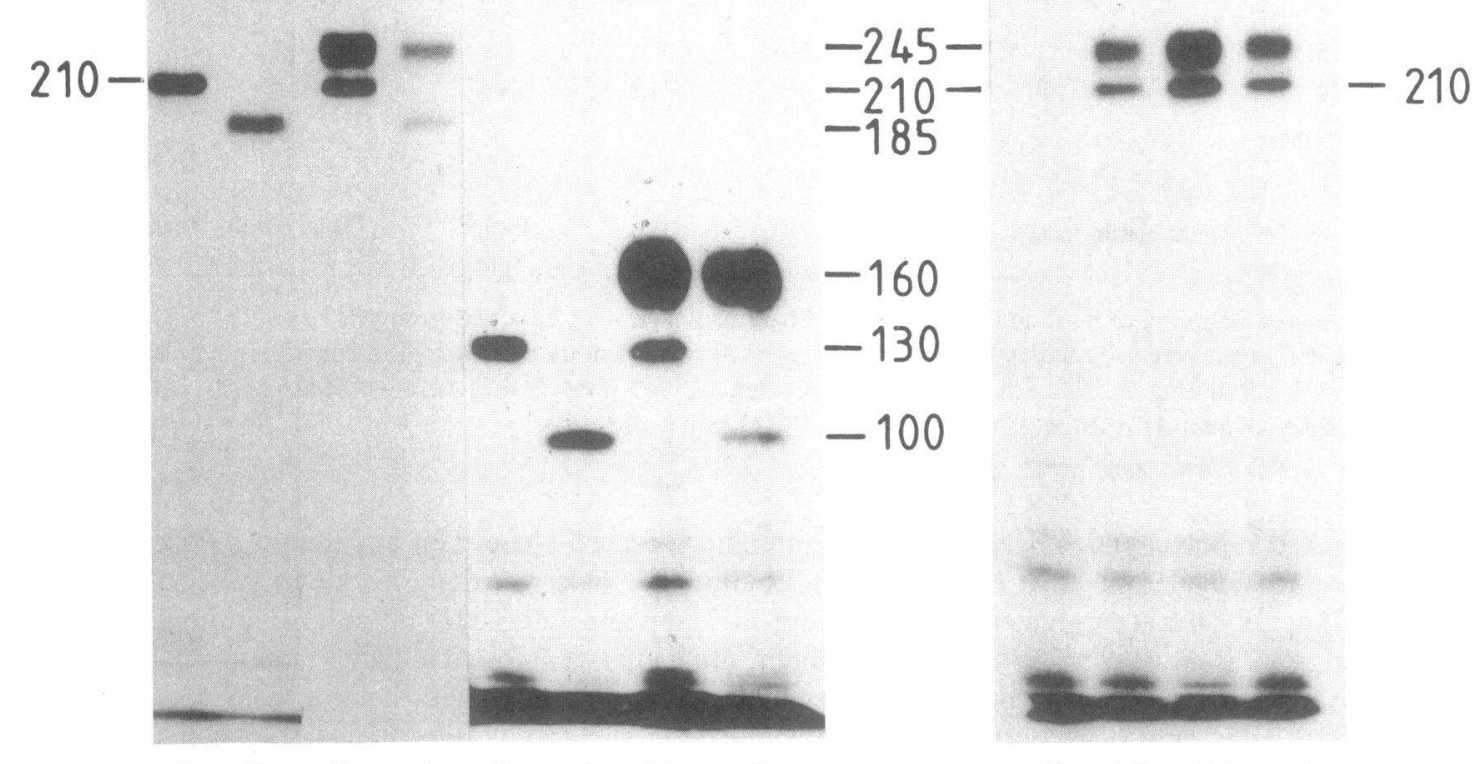

$\begin{array}{llllllllllll}1 & 2 & 3 & 4 & 5 & 6 & 7 & 8 & 9 & 10 & 11 & 12\end{array}$

C

\begin{tabular}{|l|l|l|l|l|l|}
\hline$d$ & $d$ & $n$ & $d$ & $n$ & $d$ \\
\hline
\end{tabular}

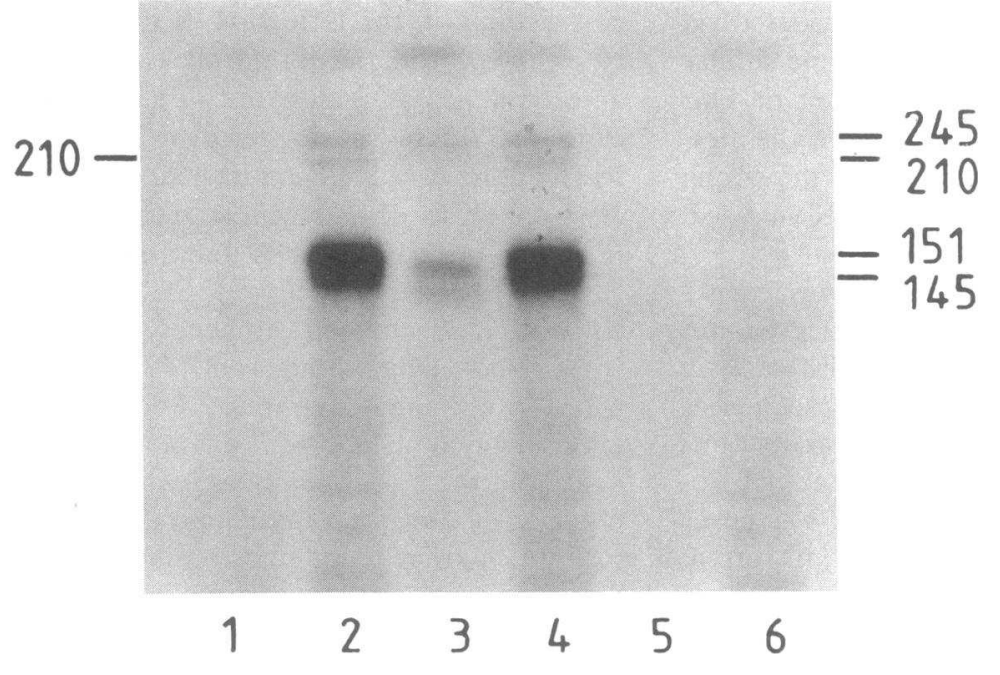



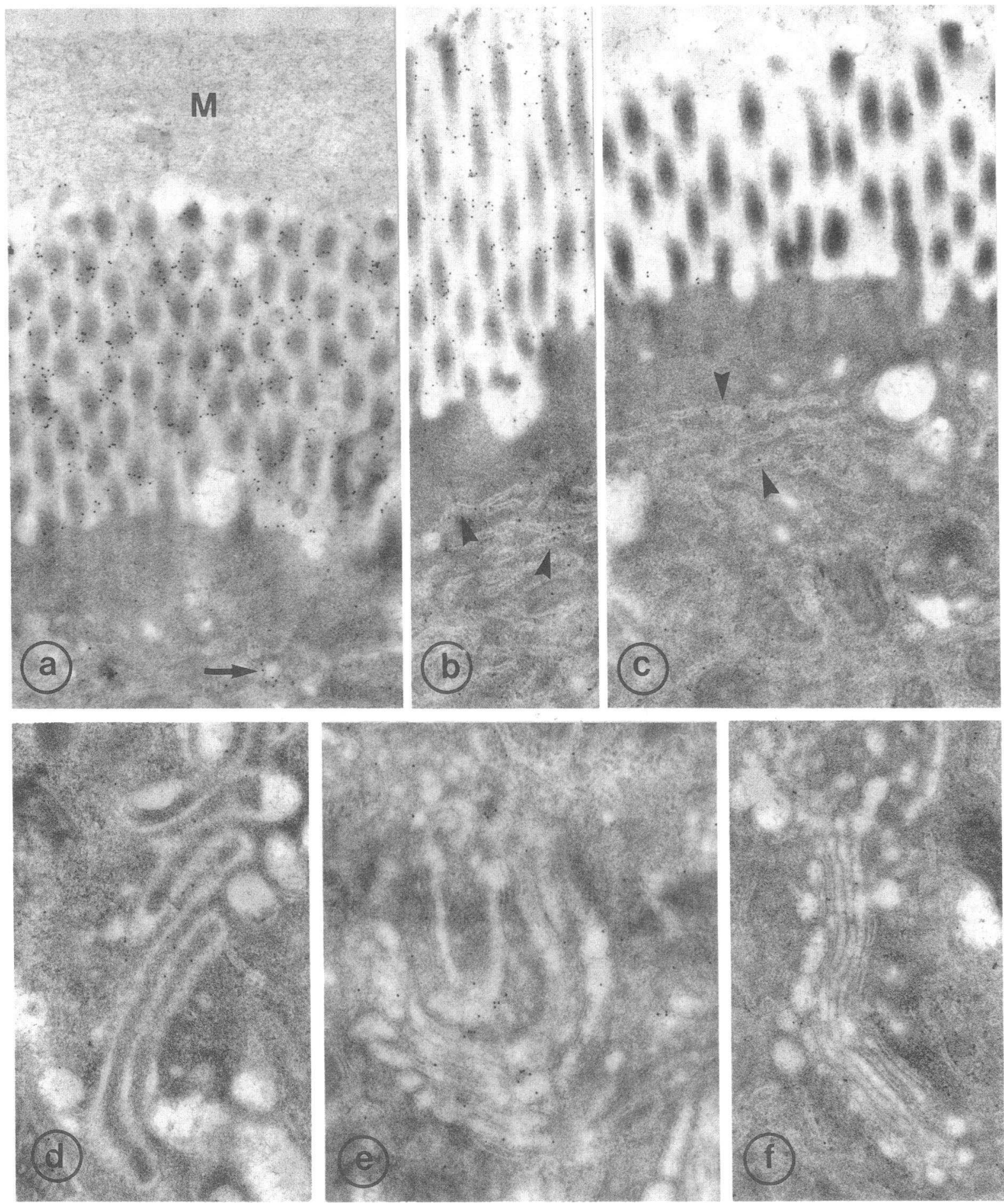

Figure 9. Immunolocalization of SI. In cases 7 and 8 immunolabel of variable intensity is present in the brush border $(a-c)$ with the adhering layer of mucus $(M)$ being unlabeled. Small cytoplasmic vesicles (arrow in $a$ ) and smooth endoplasmic reticulum (arrowheads in $b$ and $c$ ) are labeled. The basolateral plasma membrane exhibits a weak immunolabel for SI $(d)$. Immunolabel in the Golgi apparatus is of variable intensity $(e, f)$. Magnifications: $(a) 36,500 ;(b) 32,000 ;(c)$ 34,000; (d) 39,000; (e) 47,000; (f) 38,000.
Figure 8. Electrophoresis of $(A, B){ }^{35} \mathrm{~S}$-labeled and $(C)^{125} \mathrm{I}$-labeled brush border enzymes of patients 7 and 8 . Intestinal tissue fragments were labeled and immunoprecipitated as described in the legends to Figs. 1 and 3. (B) Mucosal aliquots were individually precipitated with antibodies HBB 3/705 (lane 9), HBB 1/691 (lane 10), HBB 2/219 (lane 11), and HBB 2/614 (lane 12). (C) Immunoprecipita- tion, with a mixture of four monoclonal antibodies, of SI of patient 7 (lane 2), a normal specimen (lane 3), and patient 8 (lane 4). Negative controls (antibody to the phenobarbital-inducible cytochrome P450 of rat liver) are shown for patient 7 (lane 1), the normal specimen (lane 5), and for patient 8 (lane 6 ). 
port of SI at the endoplasmic reticulum or the Golgi apparatus. Failure of SI to efficiently leave the endoplasmic reticulum appears to be correlated with a lack of a conformational change detected by monoclonal antibody HBB3/705, which shows maximal reactivity with normal pro-SI $\mathrm{H}_{\mathrm{h}}$ after a 15 -min chase but fails to recognize later forms of pro-SI $I_{h}(20)$. The epitope of this antibody has been narrowed by cDNA cloning to $\sim 100$ amino acids on the isomaltase domain of SI and was found not to comprise $\mathrm{N}$-glycosylation sites (53). One might speculate that the exit of SI from the endoplasmic reticulum requires a conformational change reflecting proper folding (54-56) which involves at least one epitope on the isomaltase domain. In line with this idea is the observation that pro-SI $\mathrm{SI}_{h}$ cases 1 and 2 which showed accumulation of cross-reacting material in the Golgi apparatus had indeed undergone this conformational change. Such a change might be necessary for binding to a transport receptor (57). Lack of transport beyond the Golgi apparatus must be due to changes in other parts of SI as indicated by case 2 in which pro-SI $\mathrm{S}_{h}$ cannot be immunoprecipitated with antibodies HBB 2/219 and HBB 1/691. However, disruption of transport at the Golgi apparatus does not correlate with an alteration of the corresponding two epitopes in case 1 .

Transport-incompetent variants designated class 2 mutations have also been found for the low density lipoprotein receptor (58). Three of these mutations were analyzed at the molecular level and the data suggested that all three of the mutations can be expected to distort the receptor in such a way that some of the cysteines can no longer form disulfide bonds. The authors proposed that unpaired cysteine residues may be available for complexing to another protein that retards movement to the cell surface or that the improperly folded protein might bind noncovalently to a hypothetical gatekeeper protein in the endoplasmic reticulum whose function is to prevent export of improperly folded proteins (59). Analysis of CSID at the gene level can be expected to provide interesting clues to the question of why these mutations disrupt the transport of SI to the cell surface.

\section{Acknowledgments}

We thank K. Bucher for expert technical assistance, Drs. H. Pflieger and $\mathbf{M}$. Kedinger for providing biopsy specimens, and $\mathrm{M}$. Liechti for secretarial help.

This work was supported by grants $3.652-0.84,3.838-0.86,3.810$ 0.86 , and 3.396-0.86 of the Swiss National Science Foundation.

\section{References}

1. Palade, G. E. 1982. Problems in intracellular membrane traffic. In Membrane Recycling. Ciba Found. Symp. 92:1-28.

2. Sabatini, D. D., G. Kreibich, T. Morimoto, and M. Adesnik. 1982. Mechanisms for the incorporation of proteins in membranes and organelles. J. Cell Biol. 92:1-22.

3. Palade, G. 1975. Intracellular aspects of the process of protein secretion Science (Wash. DC). 189:347-358.

4. Farquhar, M. G., and G. E. Palade. 1981. The Golgi apparatus (complex)-(1954-1981)-from artifact to center stage. J. Cell Biol. 91(3, pt. 2):77s-103s.

5. Kornfeld, R., and S. Kornfeld. 1985. Assembly of asparaginelinked oligosaccharides. Annu. Rev. Biochem. 54:631-664.

6. Steiner, D. F., K. Docherty, and R. Carroll. 1984. Golgi/granule processing of peptide hormone and neuropeptide precursors: a minireview. J. Cell. Biochem. 24:121-130.
7. Sefton, B. M., and J. E. Buss. 1987. The covalent modification of eukaryotic proteins with lipid. J. Cell Biol. 104:1449-1453.

8. Pfeffer, S. R., and J. E. Rothman. 1987. Biosynthetic protein transport and sorting by the endoplasmic reticulum and Golgi. Annu. Rev. Biochem. 56:829-852.

9. Kelly, R. 1987. From organelle to organelle. Nature (Lond.). 326:14-15.

10. Goldstein, J., M. S. Brown, R. G. W. Anderson, D. W. Russell, and W. J. Schneider. 1985. Receptor-mediated endocytosis: concepts emerging from the LDL receptor system. Annu. Rev. Cell Biol. 1:1-39.

11. Tartakoff, A. M. 1983. Mutations that influence the secretory path in animal cells. Biochem. J. 216:1-9.

12. Kerry, K. R., and R. R. W. Townley. 1965. Genetic aspects of intestinal sucrase-isomaltase deficiency. Aust. Paediatr. J. 1:223-235.

13. Hauri, H. P., J. Roth, E. Sterchi, and M. Lentze. 1985. Transport to cell surface of intestinal sucrase-isomaltase is blocked in the Golgi apparatus in a patient with congenital sucrase-isomaltase deficiency. Proc. Natl. Acad. Sci. USA. 82:4423-4427.

14. Semenza, G. 1986. Anchoring and biosynthesis of stalked brush border membrane proteins: glycosidases and peptidases of the enterocytes and renal tubuli. Annu. Rev. Cell Biol. 2:255-313.

15. Hauri, H. P., A. Quaroni, and K. J. Isselbacher. 1979. Biogenesis of intestinal plasma membrane: posttranslational route and cleavage of sucrase-isomaltase. Proc. Natl. Acad. Sci. USA. 76:5183-5186.

16. Hauri, H. P., A. Quaroni, and K. J. Isselbacher. 1980. Monoclonal antibodies to sucrase-isomaltase: probes for the study of postnatal development and biogenesis of the intestinal microvillus membrane. Proc. Natl. Acad. Sci. USA. 77:6629-6633.

17. Hauri, H. P., H. Wacker, E. E. Rickli, B. Bigler-Meier, A. Quaroni, and G. Semenza. 1982. Biosynthesis of sucrase-isomaltase: purification and $\mathrm{NH}_{2}$-terminal amino acid sequence of the rat sucrase-isomaltase precursor (prosucrase-isomaltase) from fetal intestinal transplants. J. Biol. Chem. 257:4522-4528.

18. Sjöström, H., O. Norén, L. Christiansen, H. Wacker, and G. Semenza. 1980. A fully active, two-active-site, single-chain sucraseisomaltase from pig small intestine: implications for the biosynthesis of a mammalian integral stalked membrane protein. J. Biol. Chem. 255:11332-11338.

19. Ghersa, P., P. Huber, G. Semenza, and H. Wacker. 1986. Cell-free synthesis, membrane integration, and glycosylation of prosucrase-isomaltase. J. Biol. Chem. 261:7969-7974.

20. Hauri, H. P., E. E. Sterchi, D. Bienz, J. A. M. Fransen, and A. Marxer. 1985. Expression and intracellular transport of microvillus membrane hydrolases in human intestinal epithelial cells. J. Cell Biol. 101:838-851.

21. Danielsen, E. M., and G. M. Cowell. 1985. Biosynthesis of intestinal microvillar proteins. The intracellular transport of aminopeptidase $\mathrm{N}$ and sucrase isomaltase occurs at different rates pre-Golgi but at the same rate post-Golgi. FEBS (Fed. Eur. Biochem. Soc.) Lett. 190:69-72.

22. Hauri, H. P. 1986. Use of monoclonal antibodies to investigate the intracellular transport and biogenesis of intestinal brush border proteins. Biochem. Soc. Trans. 14:161-163.

23. Herskovics, A., A. Quaroni, B. Bugge, and K. Kirsch. 1981. Partial characterization of the carbohydrate units of rat intestinal sucrase-isomaltase. Biochem. J. 197:511-514.

24. Frank, G., J. Brunner, H. Hauser, H. Wacker, G. Semenza, and H. Zuber. 1978. The hydrophobic anchor of small-intestinal sucraseisomaltase: N-terminal sequence of the isomaltase subunit. FEBS (Fed. Eur. Biochem. Soc.) Lett. 96:183-188.

25. Hunziker, W., M. Spiess, G. Semenza, and H. F. Lodish. 1986. The sucrase-isomaltase complex: primary structure, membrane orientation, and evolution of a stalked, intrinsic brush border protein. Cell. 46:227-234.

26. Hauri, H. P. 1988. Biogenesis and intracellular transport of intestinal brush border membrane hydrolases: use of antibody probes and tissue culture. Subcell. Biochem. In press. 
27. Dubs, R., B. Steinmann, and R. Gitzelmann. 1973. Demonstration of an inactive enzyme antigen in sucrase-isomaltase deficiency. Helv. Paediatr. Acta. 28:187-198.

28. Lloyd, M. L., and W. A. Olsen. 1987. A study of the molecular pathology of sucrase-isomaltase deficiency: a defect in the intracellular processing of the enzyme. $N$. Engl. J. Med. 316:438-442.

29. Bonkovsky, H. L., H. P. Hauri, U. Marti, U., R. Gasser, and U. A. Meyer. 1985. Cytochrome P450 of small intestinal epithelial cells: immunochemical characterization of the increase in cytochrome P450 caused by phenobarbital. Gastroenterology. 88:458-467.

30. Naim, H. Y., E. E. Sterchi, and M. J. Lentze. 1987. Biosynthesis and maturation of lactase-phlorizin hydrolase of the human small intestinal epithelial cells. Biochem. J. 241:427-434.

31. Owen, M. J., A.-M. Kissonerghis, H. F. Lodish, and M. J. Crumpton. 1981. Biosynthesis and maturation of HLA-DR antigens in vivo. J. Biol. Chem. 256:8987-8993.

32. Laemmli, U. K. 1970. Cleavage of structural proteins during assembly of the head of bacteriophage T4. Nature (Lond.). 227:680685.

33. Roth, J. 1986. Post-embedding cytochemistry with gold-labeled reagents: a review. J. Microsc. (Oxf.). 143:125-137.

34. Dahlqvist, A. 1968. Assay of intestinal disaccharidases. Anal. Biochem. 22:99-107.

35. Garen, A., and C. Levinthal. 1960. A fine-structure genetic and chemical study of the enzyme alkaline phosphatase of $E$. coli. I. Purification and characterization of alkaline phosphatase. Biochim. Biophys. Acta. 38:470-483.

36. Skovbjerg, H., and P. A. Krasilnikoff. 1986. Maltase-glucoamylase and residual isomaltase in sucrose intolerant patients. $J$. Pediatr. Gastroenterol. Nutr. 5:365-371.

37. Kobata, A. 1979. Use of endo- and exoglycosidases for structural studies of glycoconjugates. Anal. Biochem. 100:1-14.

38. Kelly, J. J., and D. H. Alpers. 1973. Blood group antigenicity of purified human intestinal disaccharidases. J. Biol. Chem. 248:82168221.

39. Triadou, N. 1984. Antigenic cross-reactions among human intestinal brush border enzymes revealed by the immunoblotting method and rabbit anti-enzyme sera. J. Immunol. Methods. 73:283291.

40. Roth, J. 1987. Subcellular organization of glycosylation in mammalian cells. Biochim. Biophys. Acta. 906:405-436.

41. Carell, R. W. 1986. Alpha-1-antitrypsin: molecular pathology, leukocytes, and tissue damage. J. Clin. Invest. 78:1427-1431.

42. Carell, R. W., J.-O. Jeppsson, C.-B. Laurell, S. O. Brennan, M. C. Owen, L. Vaughan, and D. R. Boswell. 1982. Structure and variation of human alpha-1-antitrypsin. Nature (Lond.). 298:329-334.

43. Hercz, A., E. Katona, E. Cutz, J. R. Wilson, and M. Barton. 1978. Alpha-1-antitrypsin: the presence of excess mannose in the $Z$ variant isolated from liver. Science (Wash. DC). 201:1229-1232.

44. Gray, G. M., Conklin, K. A., and R. R. W. Townley. 1976. Sucrase-isomaltase deficiency: absence of an inactive enzyme variant. N. Engl. J. Med. 294:750-753.

45. Cowell, G. M., J. Tranum-Jensen, H. Sjöström, and O. Norén. 1986. Topology and quaternary structure of prosucrase-isomaltase and final-form sucrase-isomaltase. Biochem. J. 237:455-461.
46. Williams, S. R., R. S. McIvor, and D. W. Martin. 1986. Molecular basis of human purine nucleoside phosphorylase deficiency. Cold Spring Harbor Symp. Quant. Biol. 51:1059-1064.

47. Preiser, H., D. Menard, R. K. Crane, and J. J. Cerda. 1974. Deletion of enzyme protein from the brush border membrane in sucrase-isomaltase deficiency. Biochim. Biophys. Acta. 363:279-282.

48. Schmitz, J., D. Commegrain, D. Maestracci, and J. Rey. 1974. Absence of brush border sucrase-isomaltase complex in congenital sucrose intolerance. Biomedicine. 21:440-443.

49. Schmitz, J., J. L. Bresson, N. Triadou, J. Bataille, and J. Rey. 1980. Analyse en électrophorèse sur gel de polyacrylamide des proteines de la membrane microvillositaire et d'une fraction cytoplasmique dans 8 cas de'intolérance congénitale au saccharose. Gastroenterol. Clin. Biol. 4:251-256.

50. Triadou, N., E. Audran, A. Dellon, and J. Schmitz. 1986. Heterogeneity of the defect affecting sucrase-isomaltase intracellular processing in congenital sucrose intolerance. In Ion Gradient-coupled Transport. INSERM (Inst. Natl. Santé Rech. Med.) Symp. 26:367370.

51. Freiburghaus, A. U., R. Dubs, B. Hadorn, H. Gaze, H. P. Hauri, and R. Gitzelmann. 1977. The brush border membrane in hereditary sucrase-isomaltase deficiency: abnormal protein pattern and presence of immunoreactive enzyme. Eur. J. Clin. Invest. 7:455459.

52. Skovbjerg, H., and P. A. Krasilnikoff. 1980. Immunoelectrophoretic studies on human small intestinal brush border proteins: Residual isomaltase in sucrose intolerant patients. Pediatr. Res. 15:214218.

53. Green, F., Y. Edwards, H. P. Hauri, S. Povey, M. W. Ho, M. Pinto, and D. Swallow. 1987. Isolation of a cDNA probe for a human jejunal brush border hydrolase, sucrase-isomaltase, and assignment of the gene locus to chromosome 3. Gene. 57:101-110.

54. Kreis, T., and H. Lodish. 1986. Oligomerization is essential for transport of vesicular stomatitis viral glycoprotein to the cell surface. Cell. 46:929-937.

55. Gething, M.-J., K. McCammon, and J. Sambrook. 1986. Expression of wild-type and mutant forms of influenza hemaglutinin: the role of folding in intracellular transport. Cell. 46:939-950.

56. Copeland, C. S., R. W. Doms, E. M. Bolzau, R. G. Webster, and $A$. Helenius. 1986. Assembly of influenza hemagglutinin trimers and its role in intracellular transport. J. Cell Biol. 103:1179-1191.

57. Lodish, H. F., N. Kong, M. Snider, and G. J. A. M. Strous. 1983. Hepatoma secretory proteins migrate from rough endoplasmic reticulum to Golgi at characteristic rates. Nature (Lond.). 304:80-83.

58. Russell, D. W., M. A. Lehrman, T. C. Südhof, T. Yamamoto, C. G. Davis, H. H. Hobbs, M. S. Brown, and J. L. Goldstein. 1986. The LDL receptor in familial hypercholesteremia: Use of human mutations to dissect a membrane protein. Cold Spring Harbor Symp. Quant. Biol. 51:811-819.

59. Yamamoto, T., R. W. Bishop, M. S. Brown, J. L. Goldstein, and D. W. Russel. 1986. Deletion in cysteine-rich region of LDL receptor impedes transport to cell surface in WHHL rabbit. Science (Wash. DC). 232:1230-1237. 